\title{
Ultrastructure and Chemical Composition of Lipopolysaccharide Extracted from Leptospira interrogans serovar copenhageni
}

\author{
By TU VINH, BEN ADLER AND SOLLY FAINE* \\ Department of Microbiology, Monash University, Clayton, Victoria 3168, Australia
}

(Received 3 June 1985; revised 20 August 1985)

\begin{abstract}
Lipopolysaccharide (LPS) from Leptospira interrogans serovar copenhageni was prepared from the aqueous phase of a phenol/water extract. Electron microscopic examination of negatively stained LPS showed a mixture of ribbon-like, round and ring structures. Carbohydrate analysis of the preparations revealed pentoses, hexoses, heptoses, hexosamines, and a 2-keto-3deoxyonic acid which was chromatographically different from authentic 2-keto-3-deoxyoctonic acid (KDO). The major fatty acids of the LPS were hydroxylauric, palmitic and oleic acids. Although the leptospiral LPS preparations did not contain KDO or hydroxymyristic acid, they were otherwise morphologically and chemically similar to the LPS of other Gram-negative bacteria.
\end{abstract}

\section{INTRODUCTION}

The outer envelopes and cell walls of spirochaetes, including members of the genus Leptospira, are morphologically similar to those of other Gram-negative bacteria (Pillot \& Ryter, 1965; Jackson \& Zey, 1973; Azuma et al., 1975). Jackson \& Zey (1973) found that the ultrastructure of a lipopolysaccharide (LPS) extracted from a non-pathogenic treponeme described as a strain of Treponema pallidum resembled that of LPS from Salmonella typhimurium and Escherichia coli. However, endotoxic activity characteristic of Gram-negative bacterial endotoxin could not be demonstrated in studies of the biological properties of preparations of LPS extracted from Leptospira interrogans serovar canicola (Finco \& Low, 1967; Johnson, 1976) or serovars copenhageni and pomona and from Leptospira biflexa serovar patoc (Faine et al., 1974). However, no detailed studies of the morphology and chemical composition of leptospiral LPS have been reported.

In this paper, we describe the ultrastructure and the chemical composition of an LPS extracted from the aqueous phase of a phenol/water extract (Westphal \& Jann, 1965) prepared from a virulent strain, Leptospira interrogans serovar copenhageni.

\section{METHODS}

Organisms. A strain of Leptospira interrogans serovar copenhageni (strain L45), virulent for guinea pigs (Faine \& van der Hoeden, 1964), was used, grown and maintained in a virulent form as described by Vinh et al. (1984).

Preparation and chemical treatment of leptospiral LPS. LPS was extracted from lyophilized leptospires (serovar copenhageni) by the method of Westphal \& Jann (1965). The lyophilized crude extract was dissolved in water and centrifuged at $105000 \mathrm{~g}$ for $3 \mathrm{~h}$ to remove nucleic acids. The sediment was taken up in $1 \mathrm{ml}$ of double glass-distilled water and lyophilized. Nucleic acids were not detected by UV absorption spectroscopy at $260 \mathrm{~nm}$. The LPS obtained accounted for $3-5 \%$ of total dry weight. Alkali-treated LPS was prepared by treating LPS with $0 \cdot 025 \mathrm{M}$ $\mathrm{NaOH}$ solution at a concentration of $5 \mathrm{mg} \mathrm{ml}^{-1}$ at $37^{\circ} \mathrm{C}$ for $60 \mathrm{~min}$.

Detergent-treated LPS was prepared by dissolving LPS in a $0.1 \%(w / v)$ solution of SDS $(\mathrm{BDH})$ at a concentration of $5 \mathrm{mg} \mathrm{ml}^{-1}$.

Abbreviations: KDO, 2-keto-3-deoxyoctonic acid; LPS, lipopolysaccharide 
Electron microscopy. A drop of a solution of LPS which had been lyophilized or treated with alkali or SDS and dissolved in phosphate-buffered saline ( $\mathrm{pH} \mathrm{7.2)} \mathrm{at} \mathrm{a} \mathrm{concentration} \mathrm{of} 5 \mathrm{mg} \mathrm{ml}^{-1}$ was deposited on a carbon-coated 200-mesh copper grid. Excess fluid was removed with filter paper and the grid was air-dried, and negatively stained with $2 \%(\mathrm{w} / \mathrm{v})$ sodium phosphotungstate for $30 \mathrm{~s}$. Excess staining solution was removed as above and the grid again air-dried and examined using a Philips EM 300 electron microscope at $60 \mathrm{kV}$.

$U V$ spectrum. The UV absorption spectrum of LPS solutions $\left(100 \mu \mathrm{g} \mathrm{ml}^{-1}\right)$ was recorded using a Perkin-Elmer VIS/UV spectrophotometer model 552.

Chemical analyses. Protein was measured by the micromethod of Bradford (1976) using Bio-Rad protein assay reagents. Total carbohydrate content was measured by the phenol/sulphuric acid method (Dubois et al., 1956) using glucose as standard. Hexoses, pentoses, heptoses and hexosamines were determined according to methods described by Nowotny (1979). To determine 2-keto-3-deoxyoctonic acid (KDO), $1 \mathrm{mg}$ LPS was dissolved in $0.0125 \mathrm{M}-\mathrm{H}_{2} \mathrm{SO}_{4}$ and boiled for $20 \mathrm{~min}$. The thiobarbituric acid reaction of Weissbach \& Hurwitz described by Nowotny (1979) was used to measure the keto-deoxyoctonic acid in the hydrolysate using commercial KDO (Sigma) as standard. KDO was identified by ascending paper chromatography using Whatman no. 1 filter paper with ethyl acetate/pyridine/water $(2: 1: 2$, by vol.) as solvent, and the thiobarbiturate/periodate reaction described by Nowotny (1979) was used to detect spots.

Lipid, extracted by the chloroform/methanol method of Folch et al. (1957), was dried in a rotary evaporator under vacuum followed by a stream of dry nitrogen. Phosphorus was determined according to Chen et al. (1956).

GLC analysis of neutral sugars. Samples of LPS were dissolved in $0 \cdot 5 \mathrm{M}-\mathrm{H}_{2} \mathrm{SO}_{4}$ at a concentration of $5 \mathrm{mg} \mathrm{ml}^{-1}$ and heated at $100^{\circ} \mathrm{C}$ for $4 \mathrm{~h}$. The hydrolysate was neutralized by drying over sodium hydroxide pellets in a vacuum desiccator. Trimethylsilyl derivatives were prepared by adding to the dry sample $100 \mu$ l of a solution of TRISIL (Pierce Chemicals). The mixture was kept at room temperature for $30 \mathrm{~min}$ and then samples of $1 \mu \mathrm{l}$ were injected into a Varian 3700 gas-liquid chromatograph equipped with a stainless steel $2.4 \mathrm{~m} \times 0.6 \mathrm{~cm}$ column packed with $5 \%$ SE 30 on Chromosorb W-HP 80/100 mesh. Nitrogen carrier gas at a flow rate of $30 \mathrm{ml} \mathrm{min}^{-1}$ and a flame ionization detector were used. The temperature programme started at $160^{\circ} \mathrm{C}$ for $1 \mathrm{~min}$, increasing to a maximum temperature of $230^{\circ} \mathrm{C}$ at a rate of $2{ }^{\circ} \mathrm{C} \mathrm{min}-1$. The injector and detector temperatures were $200{ }^{\circ} \mathrm{C}$ and $250^{\circ} \mathrm{C}$ respectively. The sugars were identified by comparison with known standard sugars obtained from Mann Research Laboratory, New York, USA.

GLC analysis of fatty acids. Fatty acids were methylated as follows. The dried chloroform extract was treated with $5 \mathrm{ml}$ of a solution of $5 \%(\mathrm{w} / \mathrm{v}) \mathrm{NaOH}$ in $50 \%(\mathrm{w} / \mathrm{v})$ methanol in water for $30 \mathrm{~min}$ at $100{ }^{\circ} \mathrm{C}$, cooled to room temperature and $6 \mathrm{M}-\mathrm{HCl}$ was added to bring the mixture to $\mathrm{pH} 2 \cdot 0$, followed by $5 \mathrm{ml} 10 \%(\mathrm{w} / \mathrm{v})$ borotrichloride/methanol reagent (Applied Science Laboratories). The mixture was heated for $5 \mathrm{~min}$ at $80{ }^{\circ} \mathrm{C}$ to facilitate methylation. The methylated fatty acids were extracted with light petroleum (b.p. $\left.40-60^{\circ} \mathrm{C}, \mathrm{BDH}\right)$ and concentrated to a volume of $50 \mu \mathrm{l}$ by using a stream of dry nitrogen. A $3 \mu \mathrm{l}$ sample was injected into a Packard 427 gas chromatograph containing a $1.8 \mathrm{~m} \times 0.6 \mathrm{~cm}$ glass column packed with $3 \%$ Supelco GP SP2100 on $100 / 120$ mesh Supelcoport. The temperature was programmed from $130{ }^{\circ} \mathrm{C}$ to $215^{\circ} \mathrm{C}$ at a rate of $5{ }^{\circ} \mathrm{C} \mathrm{min}{ }^{-1}$. The fatty acid profile was identified by comparison with known standard fatty acids.

\section{RESULTS}

\section{Ultrastructure of leptospiral LPS}

Negatively stained preparations of leptospiral LPS (extracted from L. interrogans serovar copenhageni) showed ribbon-like forms, some of trilaminar appearance, 10-12 nm wide, spread in sheets of closely-packed straight, looped, circular and round shapes (Figs 1 and 2).

After alkali treatment the LPS was transformed into a relatively homogeneous suspension of particles $2-5 \mathrm{~nm}$ in diameter (Fig. 3). Treatment of LPS with SDS induced the formation of short swollen strands and irregularly shaped strands, amongst which a few trilamellar straight fragments were seen (Fig. 4). The UV absorption maximum of leptospiral LPS was located sharply at approximately $192 \mathrm{~mm}(A 0.60)$ with a small shoulder at $235 \mathrm{~nm}(A 0.08)$. The absorbance above $250 \mathrm{~nm}$ was less than 0.04 .

\section{Chemical analysis of leptospiral LPS}

Leptospiral LPS accounted for 3-5\% of the total cellular dry weight. The general chemical composition of the leptospiral LPS was $5.4 \%$ protein, $33.3 \%$ lipid, $32 \%$ pentoses, $12 \%$ hexoses, $4.5 \%$ heptoses, $1 \%$ amino sugars, $0.45 \%$ 2-keto-3-deoxyonic acid and $0.4 \%$ phosphorus. When the 2-keto-3-deoxyonic acid detected by the thiobarbituric acid reaction was subjected to paper chromatography using authentic KDO as standard, its $R_{F}$ value of 0.28 was different from the $R_{F}$ 


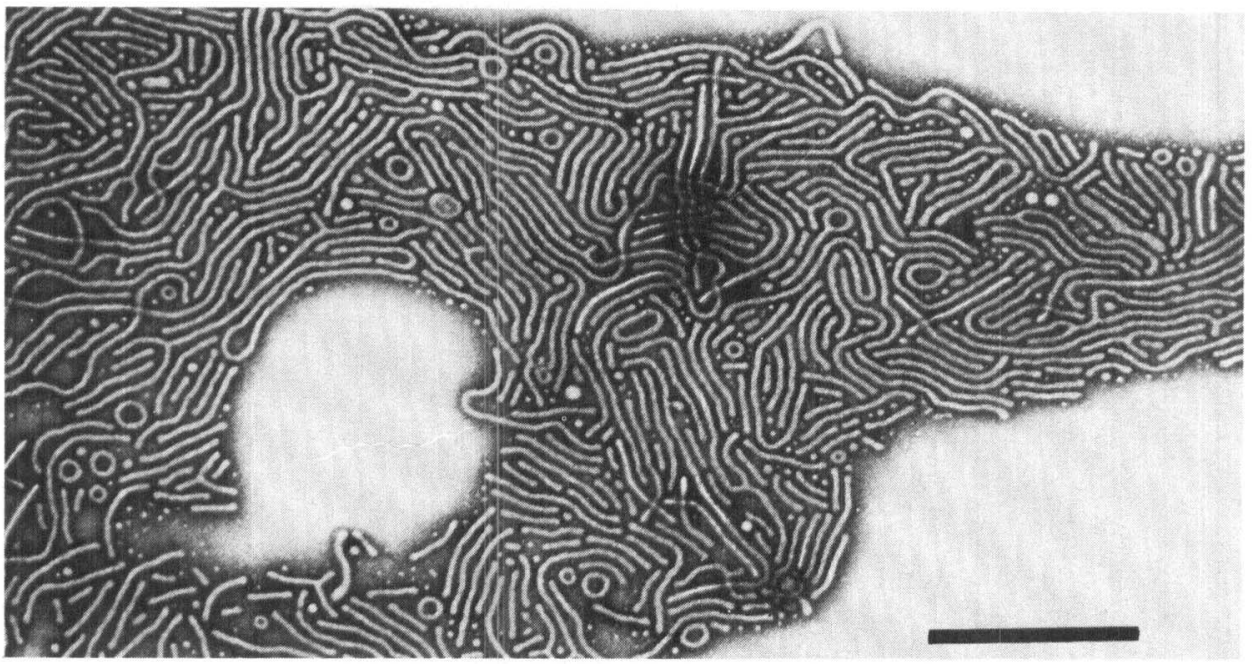

Fig. 1. Electron micrograph of leptospiral LPS negatively stained with $2 \%(w / v)$ phosphotungstic acid. Bar, $0.5 \mu \mathrm{m}$.

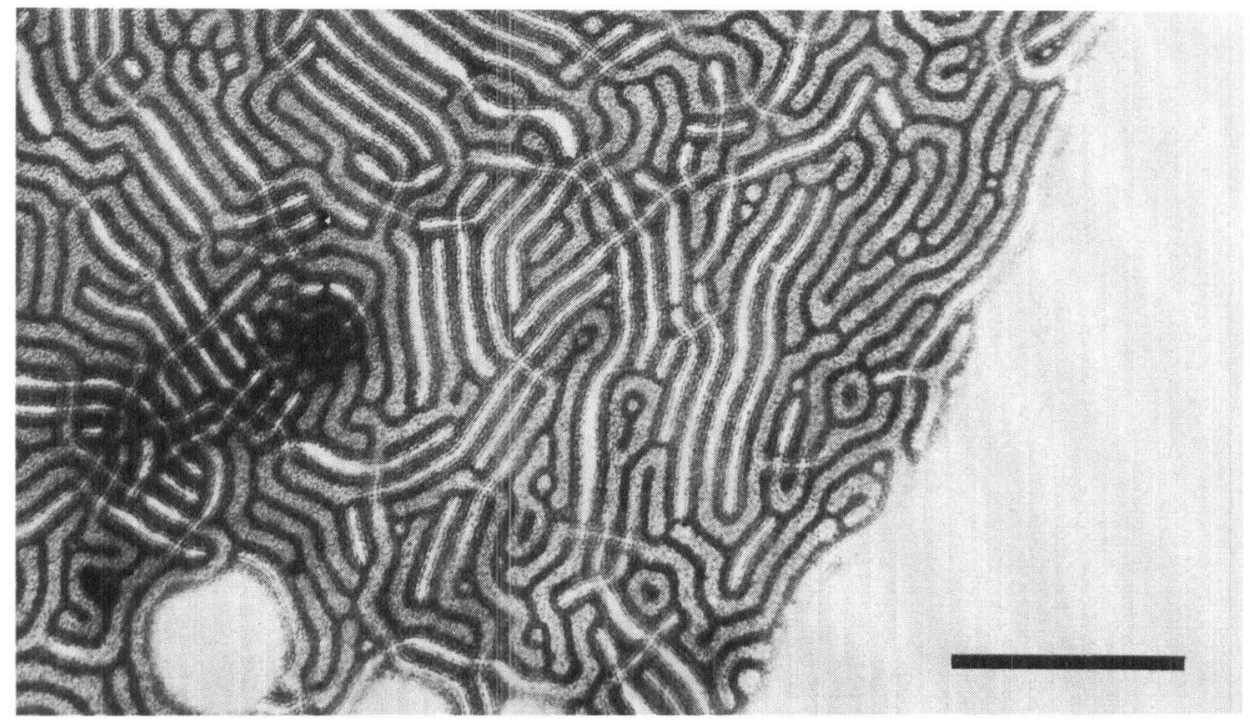

Fig. 2. Electron micrograph of leptospiral LPS negatively stained with $2 \%(w / v)$ phosphotungstic acid showing trilaminar structure. Bar, $0 \cdot 2 \mu \mathrm{m}$.

value of 0.47 found for a sample of authentic KDO. The identity of this compound has not been established.

The results of GLC of trimethylsilyl derivatives of the sugars are shown in Table 1 . The main group of sugars, the pentoses, comprised $83.9 \%$ of the total carbohydrates, while hexoses were $8.9 \%$ and amino hexoses were $7.5 \%$.

Treatment of LPS with $0 \cdot 2 \mathrm{M}-\mathrm{H}_{2} \mathrm{SO}_{4}$ resulted in the liberation of lipid A. The fatty acid composition of lipid A from leptospiral LPS is shown in Table 2. 3-Hydroxylauric acid (3-OH$\left.\mathrm{C}_{12: 0}\right)$, palmitic acid $\left(\mathrm{C}_{16: 0}\right)$ and oleic acid $\left(\mathrm{C}_{18: 1}\right)$ were the main fatty acids of leptospiral LPS. Myristic $\left(\mathrm{C}_{14: 0}\right)$ and 3-hydroxymyristic (3-OH- $\left.\mathrm{C}_{14: 0}\right)$ acids were not found. 


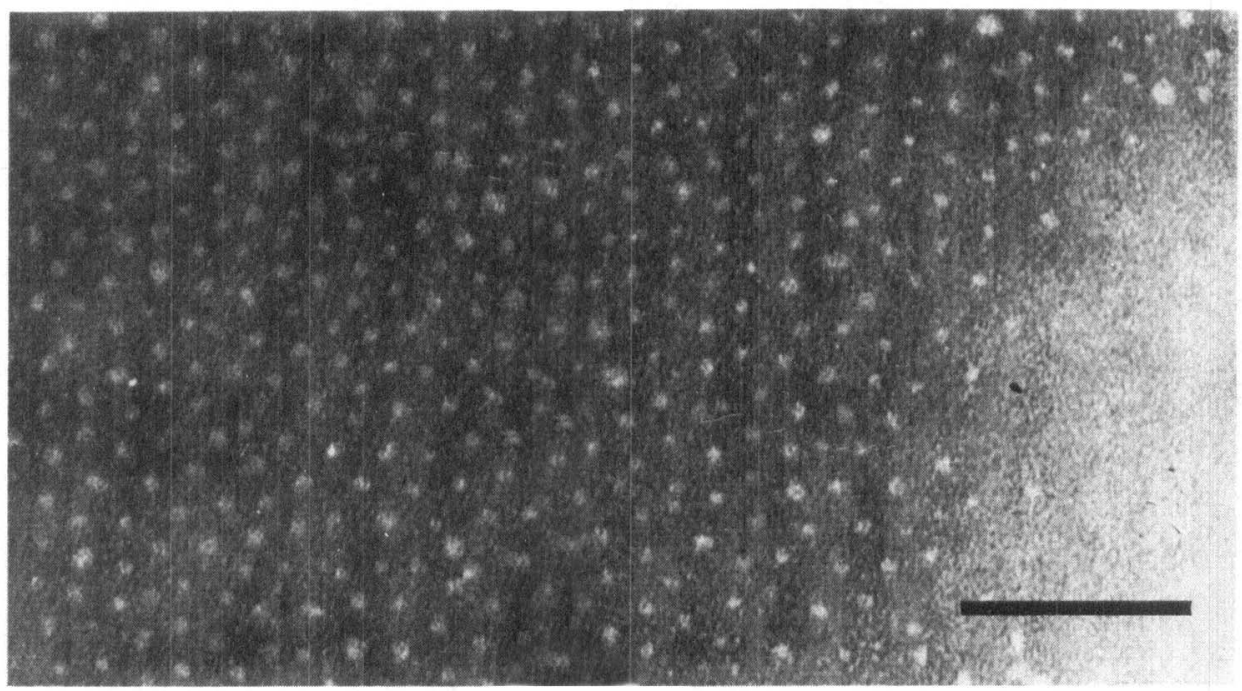

Fig. 3. Electron micrograph of alkali-treated leptospiral LPS negatively stained with $2 \%(\mathrm{w} / \mathrm{v})$ phosphotungstic acid. Bar, $0 \cdot 1 \mu \mathrm{m}$.

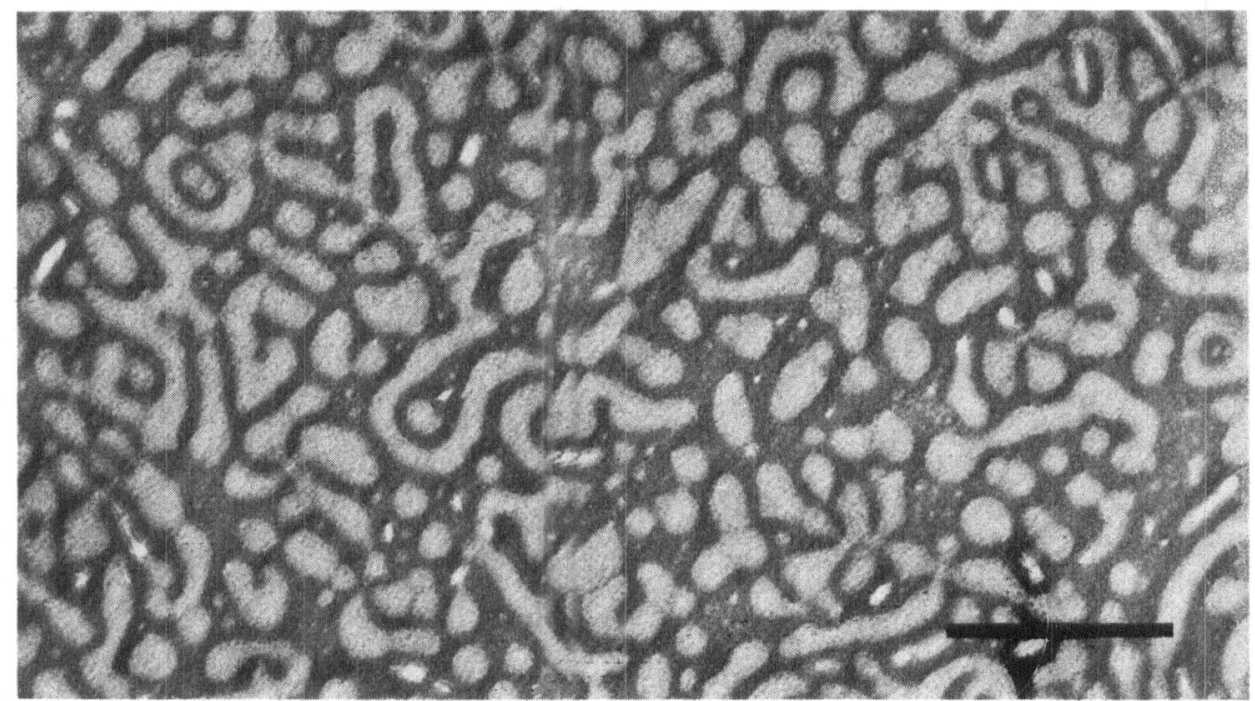

Fig. 4. Electron micrograph of SDS-treated leptospiral LPS negatively stained with $2 \%$ (w/v) phosphotungstic acid. Bar, $0 \cdot 2 \mu \mathrm{m}$

\section{DISCUSSION}

Electron microscopic examination of negatively stained LPS extracted from $L$. interrogans serovar copenhageni showed ribbon-like structures similar to that reported from LPS from Escherichia coli (Lopes \& Inniss, 1970), Salmonella typhimurium (Shands et al., 1967) and Treponema pallidum (Jackson \& Zey, 1973). Nothing is known of 'smooth' and 'rough' equivalents in Leptospira, but it appears that the leptospiral LPS examined may be in a smooth form because its ultrastructure shows two dense lines, running parallel to the length of the ribbons, similar to the structure shown by Lopes \& Inniss (1970) to represent the O-specific side chains which were not present in the rough form LPS of $E$. coli. The strain of leptospires used was maintained in a virulent state by frequent passage through guinea pigs. 
Table 1. GLC analysis of trismethylsilyl derivatives of neutral sugars of LPS extracted from L. interrogans serovar copenhageni (strain L45)

Results are the means of two determinations \pm the range and are expressed as a percentage of the total carbohydrate fraction.

$\begin{array}{lr}\text { Sugar } & \begin{array}{r}\text { Percentage } \\ \text { composition }\end{array} \\ \text { Rhamnose } & 45 \cdot 6 \pm 1 \cdot 0 \\ \text { Arabinose } & 13.5 \pm 0.9 \\ \text { Fucose } & 9 \cdot 1 \pm 0 \cdot 7 \\ \text { Xylose } & 24.9 \pm 0 \cdot 3 \\ \text { Mannose } & 3.4 \pm 0 \cdot 1 \\ \text { Galactose } & 2 \cdot 3 \pm 0 \cdot 2 \\ \text { Glucose } & 5 \cdot 0 \pm 0.5 \\ \text { Galactosamine } & 2.3 \pm 0 \cdot 2 \\ \text { Glucosamine } & 7 \cdot 5 \pm 1.0\end{array}$

Table 2. GLC analysis of fatty acid composition of LPS extracted from L. interrogans serovar copenhageni (strain L45)

Results are the means of two determinations \pm the range and are expressed as a percentage of the total lipid fraction.

Fatty acid

Hydroxydecanoic (3-OH- $\left.\mathrm{C}_{10: 0}\right)$

Lauric $\left(\mathrm{C}_{12: 0}\right)$

Hydroxylauric (3-OH-C $\mathrm{C}_{12: 0}$ )

Hydroxypentadecanoic $\left(\mathrm{OH}-\mathrm{C}_{15: 0}\right)$

Palmitoleic $\left(\mathrm{C}_{16: 1}\right)$

Palmitic $\left(\mathrm{C}_{16: 0}\right)$

Hydroxypalmitic (2-OH-C $\mathrm{C}_{16: 0}$ )

Hydroxyheptadecanoic $\left(\mathrm{OH}-\mathrm{C}_{17: 0}\right)$

Oleic $\left(\mathrm{C}_{18: 1}\right)$

Stearic $\left(C_{18: 0}\right)$

\section{Percentage}

composition

$7 \cdot 1 \pm 0 \cdot 4$

$2 \cdot 5 \pm 0 \cdot 1$

$30.5 \pm 0.9$

$4 \cdot 6 \pm 0 \cdot 1$

$2 \cdot 5 \pm 0 \cdot 2$

$17 \cdot 0 \pm 1 \cdot 0$

$1 \cdot 4 \pm 0 \cdot 1$

$1.6 \pm 0.2$

$10.7 \pm 0.1$

$5 \cdot 0 \pm 0 \cdot 2$

Mild alkali treatment degraded leptospiral LPS into small particles, similar to those seen in alkali-treated Gram-negative LPS, which has a greater affinity than untreated LPS to bind to erythrocytic membranes (Ciznar \& Shands, 1971). Alkali treatment was shown to enhance erythrocyte binding of a leptospiral LPS preparation (Faine et al., 1974). Thus morphologically leptospiral LPS resembles typical LPS of Gram-negative enteric bacteria.

The UV absorption spectrum indicated a single peak (absorption maximum 0.60 at $192 \mathrm{~nm}$ ) and a small shoulder at $235 \mathrm{~nm}$ (absorption maximum 0.08) which appears to correspond to an absorption maximum similar to the TM antigen described by Shinagawa \& Yanagawa (1972).

Leptospiral LPS has a chemical composition similar to most Gram-negative bacterial LPS, except for the absence of hydroxymyristic acid $\left(3-\mathrm{OH}-\mathrm{C}_{14}\right)$, a common marker from enteric group LPS, and KDO. The 2-keto-deoxy sugar acid found in leptospiral LPS was not KDO because of its different migration on paper chromatography. Since all 2-keto-3-deoxy sugar acids react with periodic and thiobarbituric acids giving a pink colour absorbed at $549 \mathrm{~nm}$ (Ghalambor et al., 1966; Luderitz et al., 1971), the corresponding deoxy sugar has to be determined in order to identify a reactive 2-keto-3-deoxy sugar acid. These observations confirm those of Shimizu et al. (1984) who also found an unidentified KDO-like component in LPS isolated from L. interrogans serovar canicola. Kasai \& Nowotny (1967) also found 3 thiobarbituric acid-positive spots on high voltage paper electrophoresis while studying the sugar composition of a Salmonella minnesota glycolipid. 2-Keto-deoxy acids or their phosphorylated forms have been shown to be intermediates in the metabolism of carbohydrates by bacteria. 
Examples are 2-keto-3-deoxygluconic acid 6-phosphate, an intermediate in the metabolism of glucose (Entner \& Doudoroff, 1952; Wood \& Schwerdt, 1954); and 2-keto-3-deoxyheptonic acid 7-phosphate, an intermediate in aromatic amino acid biosynthesis (Weissbach \& Hurwitz, 1959).

No attempt has been made to identify all the components of LPS. Ono et al. (1984) described components of an antigenic fraction (TM) of L. interrogans serovar canicola, related to LPS (Adler et al., 1980), emphasizing the difficulties arising from the small amounts of material available, even though they extracted $1000 \mathrm{l}$ of culture.

The absence of endotoxic activity such as pyrogenicity, mouse lethality and cytotoxicity for cultured L-cell fibroblasts (Vinh et al., 1986) confirms the observations of Finco \& Low (1967) and Johnson (1976) for leptospiral LPS. Hardy \& Levin (1983) were unable to demonstrate endotoxic activities in Borrelia and Treponema pallidum infections.

KDO is a linkage between lipid A and polysaccharide chains in LPS from other Gramnegative bacteria, but plays no role in the endotoxic activity which is entirely dependent on lipid A (Luderitz et al., 1971; Amano et al., 1983). Furthermore the removal from LPS of lauryl, myristyl and 3-hydroxymyristyl groups by alkaline hydroxylaminolysis was associated with the reduction of pyrogenicity and low toxicity for mice and dogs (McIntire et al., 1967).

It is not known whether the absence of myristic acid $\left(\mathrm{C}_{14: 0}\right)$ and 3-hydroxymyristic (3-OH$\mathrm{C}_{14: 0}$ ) acids, which are the main fatty acids of the other Gram-negative bacterial LPS (Galanos et al., 1977), is the reason why leptospiral LPS lacks endotoxic activity characteristic of LPS from enteric bacteria. Toxic activity similar to some characteristics of typical Gram-negative bacterial LPS was found in another type of preparation from leptospires (Vinh et al., 1986).

This work was supported by a grant from the National Health and Medical Research Council, Canberra, Australia. We thank Dr Peter Coloe, Veterinary Research Institute, for the fatty acid analysis and Mr Wayne Christopher for excellent technical assistance.

\section{REFERENCES}

Adler, B., Faine, S. \& Yanagawa, R. (1980). Comparative studies on two antigens (F4 and TM) extracted from leptospires. Journal of Clinical Microbiology 12, 7-9.

Amano, K., Ribi, E. \& Cantrell, J. L. (1983). Structural requirements of endotoxic glycolipid for antitumor and toxic activity. Journal of Biochemistry 93, 1391-1399.

azuma, I., Taniyama, T., Yamamura, Y., Yanagihara, Y., Hattori, Y., Yasuda, S. \& Mifuchi, I. (1975). Chemical studies on the cell wall of Leptospira biflexa strain Urawa and Treponema pallidum strain Reiter. Japanese Journal of Microbiology 19 , 45-51.

BRADFORD, M. (1976). A rapid and sensitive method for the quantitation of microgram quantities of protein utilizing the principle of protein-dye binding. Analytical Biochemistry 72, 248-254.

Chen, P. S., JR, Toribara, T. Y. \& Warner, H. (1956). Microdetermination of phosphorus. Analytical Biochemistry 28, 1756-1758.

Ciznar, I. \& ShandS, J. W., JR (1971). Effect of alkalitreated lipopolysaccharide on erythrocyte membrane stability. Infection and Immunity 4, 362-367.

Dubois, M., Gilles, K. A., Hamilton, J. K., Rebers, P. A. \& SMITH, F. (1956). Colorimetric method for determination of sugars and related substances. Analytical Chemistry 28, 350-356.

ENTNER, N. \& Doudoroff, M. (1952). Glucose and gluconic acid oxidation of Pseudomonas saccharophila. Journal of Biological Chemistry 196, 853-862.
FAINe, S. \& VAN DER HoEden, J. (1964). Virulencelinked colonial and morphological variation in Leptospira. Journal of Bacteriology 88, 1493-1496.

Faine, S., Adler, B. \& PAlit, A. (1974). Chemical and serological properties of a serotype-specific polysaccharide antigen in Leptospira. Australian Journal of Experimental Biology and Medical Sciences 52, 311319.

FINCo, D. R. \& Low, D. G. (1967). Endotoxin properties of Leptospira canicola. American Journal of Veterinary Research 28, 1863-1872.

Folch, J., LeEs, M. \& Sloane-Stanley, G. H. (1957). A simple method for the isolation and purification of total lipides from animal tissues. Journal of Biological Chemistry 226, 497-509.

Galanos, C., Luderitz, O., Rietschel, E. T. \& WestPhal, O. (1977). Newer aspects of the chemistry and biology of bacterial lipopolysaccharides, with special reference to their lipid A component. In International Review of Biochemistry: Biochemistry of Lipids II, vol. 14, pp. 239-335. Edited by T. W. Goodwin. Baltimore: University Park Press.

Ghalambor, A., LeVine, E. M. \& Heath, E. C. (1966). The biosynthesis of cell wall lipopolysaccharide in Escherichia coli. III. The isolation and characterization of 3-deoxyoctulosonic acid. Journal of Biological Chemistry 211, 3207-3215.

HARDY, P. H., JR \& Levin, J. (1983). Lack of endotoxin in Borrelia hispanica and Treponema pallidum. Proceedings of the Society for Experimental Biology and Medicine 174, 47-52. 
JACKSON, S. W. \& ZEY, P. N. (1973). Ultrastructure of lipopolysaccharide isolated from Treponema pallidum. Journal of Bacteriology 114, 838-844.

JoHnson, R. C. (1976). Comparative spirochete physiology and cellular composition. In The Biology of Parasitic Spirochetes, pp. 39-48. Edited by R. C. Johnson. New York: Academic Press.

Kasal, N. \& Nowotny, A. (1967). Endotoxic glycolipid from a heptoseless mutant of Salmonella minnesota. Journal of Bacteriology 94, 1824-1836.

LOPES, J. \& INNISS, W. E. (1970). Electron microscopic study of lipopolysaccharide from an avian strain of Escherichia coli O18. Journal of Bacteriology 103, 238-243.

Lüderitz, O., Westphal, O., Staub, A. M. \& NikaIDO, H. (1971). Isolation and chemical and immunological characterization of bacterial lipopolysaccharides. In Microbial Toxins, vol. IV, pp. 145-233. Edited by G. Weinbaum, S. Kadis \& S. J. Ajl. New York \& London: Academic Press.

Mcintire, F. C., Stevert, H. W., Barlow, G. H., Finley, R. A. \& LeE, A. Y. (1967). Chemical, physical, and biological properties of a lipopolysaccharide from Escherichia coli K-235. Biochemistry 6, 2363-2372.

Nowotny, A. (1979). Basic Exercises in Immunochemistry: a Laboratory Manual. Berlin: SpringerVerlag.

ONo, E., NAIKI, M. \& YanaGaWA, R. (1984). Isolation of an antigenic oligosaccharide fraction from Leptospira interrogans serovar canicola with a monoclonal antibody. Journal of General Microbiology 130, 14291435.

Pillot, J. \& Ryter, A. (1965). Structure des spiro- chètes. I. Étude des genres Treponema, Borrelia et Leptospira au microscope électronique. Annales de l'Institut Pasteur 108, 701-804.

Shands, J. W., Graham, J. A. \& Nath, K. (1967). The morphologic structure of isolated bacterial lipopolysaccharide. Journal of Molecular Biology 5, 15-21.

Shimizu, T., MasusaKa, E., Yanagihara, Y. \& MifUCHI, I. (1984). Studies on endotoxin of Leptospira. Japanese Journal of Bacteriology 39, 345 (in Japanese).

Shinagawa, M. \& Yanagawa, R. (1972). Isolation and characterization of a leptospiral type-specific antigen. Infection and Immunity 5, 12-19.

ViNH, T., FaINe, S. \& AdLER, B. (1984). Adhesion of leptospires to mouse fibroblasts (L929) and its enhancement by specific antibody. Journal of Medical Microbiology 18, 73-85.

VINH, T., AdLer, B. \& FAINE, S. (1986). Glycolipoprotein cytotoxin from Leptospira interrogans serovar copenhageni. Journal of General Microbiology 132, 111-123.

WeissBaCH, A. \& HuRWItz, J. (1959). The formation of 2-keto-3-deoxyheptonic acid in extracts of Escherichia coli B. I. Identification. Journal of Biological Chemistry 234, 705-709.

WeStPhal, O. \& JANN, K. (1965). Bacterial lipopolysaccharides: extraction with phenol-water and further applications of the procedure. Methods in Carbohydrate Chemistry 5, 83-91.

WOOD, W. A. \& SCHWERd, R. F. (1954). Carbohydrate oxidation by Pseudomonas fluorescens. II. Mechanism of hexose phosphate oxidation. Journal of Biological Chemistry 206, 625-635. 